\title{
Exploring the Correlation Between Students' Interest in Listening and Listening Comprehension in English Context
}

\author{
Widia Yunita \& Jumiyanti Jumiyanti \\ STAI Hubbulwathan, Duri. Indonesia \\ widiayunita136@gmail.com
}

\begin{abstract}
ARTICLE HISTORY
Received : 2020-09-07

Revised : 2020-10-27

Accepted : 2020-11-09
\end{abstract}

\section{KEYWORDS}

Students'interest listening comprehension

Language acquisition

Correlational study

\begin{abstract}
The beginning of our learning is from hearing. Because of that, many educational experts and educational theories claim that the first learning activity is auditory. The influence of students' listening comprehension, such as cognitive factors and psychological aspects also involved. One of the psychological problems is students' interest. The purpose of this research is to find out a significant correlation between students' interest in listening and their listening comprehension on the eleventh-grade students of SMKN 3 Tanah Putih, Rokan Hilir. The sample of this research was 26 students. The technique used in this research was correlational. In collecting the data, this research was distributing questionnaires to the respondents to assess students' interests. Besides, in assessing students' listening comprehension, this research conducted a listening test for the students. In analyzing the data, the questionnaires were assessed by Likert's scale rating. The result of this research showed that the score of Sig. (2-tailed) gathered from SPSS 22, it was found that Sig. (2-tailed) the result was 0.001 . Because of Sig. (2-tailed) was smaller than 0.05 , it can be concluded that the null hypothesis (Ho) was rejected, and the alternative hypothesis (Ha) was accepted, which is states there is a significant correlation between students' interest in listening and their listening comprehension. In conclusion, there is a positive correlation between students' interest in listening and their listening comprehension. It means that students with higher interest will get better listening comprehension than the lower one. In other words, the higher interested students, the better listening comprehension can be achieved.
\end{abstract}

\section{Introduction}

English is a language used in all aspects of communication, science, and technology. All of them can be actualized through speaking and other basic skill such as listening, reading, and writing. English is an international language (Richards, 2008, p.2). Karagöz et al. (2017) added that the most pivotal tool of effective communication among people has been the language all the time. One of the four skills which play a significant role in mastering English language is listening. The first experience that students acquired by the time they were born were much influenced by listening. Listening is a very active process means that when we listen not only we deal with what is heard but also we combine it that are already familiar (Ulum, 2015).

The beginning of our learning is from hearing, because of that many educational experts and educational theories claim that the first learning activity is auditory (through the listening process). Listening plays a vital role in daily lives. Saville (2012, p. 169) stated listening is a critically important activity. People listen for different purposes such as entertainment, academic purposes or obtaining necessary information. Without listening, no communication can be achieved.

Sa'diyah (2016, p.58) based on the research reveals that listening comprehension is difficult. Students in Indonesia think that listening is difficult because many aspects should be considered such as the cognitive process and psychological aspects involved within. Because of these aspects, listening comprehension is difficult to be mastered to the students. Meanwhile, listening is an important skill for students especially in teaching and learning process. Through listening they get knowledge whether electronic media or people. Most of their time is used to sitting in the class and listening to their teacher or friend.

Some phenomenon faced by students in listening is the students could not get the specific information from the native speaker's conversations, the students could not get the general and specific information from the spoken text, the students failed to determine the meaning of the word based on context, the specific information, the dialog take place, and the students 
cannot interpret the meaning of the speaker in comprehending the native speaker's dialog.

From the problems mentioned above, it can be seen that not only teaching method and strategies which influence students' listening comprehension but other factors such as cognitive factor and psychological aspects also involved. One of the psychological problems is students' interest. In general, the interest can be interpreted as a tendency that causes a person trying to look for or try activities in a specific field. Interest is a positive attitude towards environmental aspects. Further

Syah (2006) defines interest as a high inclination and excitement or a great desire for something. Interest implies a desire attention or doing anything. Interest also means something you like without any associated or unwillingly. According to Djali (2011), interest is pleasure or continuous attention to an object for their hope of gain emergence. In this research, the interest means the students' interest in listening.

From the quotation above, it shows that students' interest will drive people to do something. For example, a person who likes singing will sing more and more. Besides, they might be eager to learn how to sing. The case is same as in listening. If students like to listen, they will try to listen more and more. From the example above, the researcher assumes that students with higher interest in listening comprehension are supposed to listen more and learn how to listen more than those with lower interest. As a result, students with higher interest will get a better score in listening comprehension than those with lower interest.

The previous research about interest has done by the other researcher. The finding of the study shows the students' interest could influence their achievement. Students who have high interest try to pursue knowledge more than who have the low one. They tend to be more attentive in learning the lesson. They enjoy and ready to do any task given by teacher. They learn English in school and also out of the school. They are motivated to enrich their vocabulary, to practice their English and do a lot of exercises to make them more skillful in using English.

On the other side, students who have low interest look bored while studying, disturbing their friends. In other words, they are looking for attention (Firmani, 2009; Chasanah, 2017).

This research investigated the correlation between students' interest and listening comprehension. The study results can be a consideration for teachers in designing appropriate learning process in listening comprehension. This is of course very important in achieving the goal learning.

\section{Method}

This study used a quantitative research. The study's design was correlational researchquantitative research is concerned with the collection and analysis of data in numeric form. Creswell (2008, p.356) states that this research is a quantitative method of research in which investigators measure the degree of association or relation between two or more variables using the statistical procedure of correlation analysis. The researcher has researched from July until September 2020. The research was carried out at SMKN 3 Tanah Putih, Rokan Hilir, Riau in the academic year of 2020/2021.

This research population was the eleventh-grade of SMKN 3 Tanah Putih in the academic year of $2020 / 2021$. The number of population was 26. Gay (2012, p.139) also added, for smaller populations, say, $\mathrm{N}=100$ or fewer, there is little point in sampling; survey the entire population. Because the total population is 26 fewer than 100 , the researcher took all of the entire population.

In collecting the data, the researcher used questionnaire. The questionnaire used in this research was the standard questionnaires which consist of students' interest. This questionnaire is adopted from Suhadi (2018). The questionnaire consisted of 20 question items. It assessed the indicators of interest such as pleasure, willingness, consciousness, and attention.

To find the scores of the students' interest, score five was given to the answer of absolutely agree and score one was given to the answer of absolutely disagree. A Likert scale rating assessed the questionnaire. This scale rating had five options. They are: Strongly Agree, Agree, Undecided, Disagree and Strongly Disagree.

In order to know the students listening comprehension, the measurement could be given in test form. According to Brown (2004, p.3), a test is a method of measuring a person's ability or knowledge in a given area. In this test, the students were given 15 questions in written form. The researcher gave 40 minutes to finish listening test. The researcher made calculation of the score obtained by student from the listening comprehension test in order to measure how much they have master listening skill.

After collecting the data, the next step was to analyze them to know whether there is significant correlation between students' interest in listening and their listening comprehension. In this step, the researcher used the correlation technique by using Product Moment Formula. The researcher compared the score of students' interest in listening and their 
listening comprehension. This technique is useful to prove statistically whether there is any significant correlation between two variables. To find the correlation between students' interest in listening and their listening comprehension on the eleventh-grade students of SMKN 3 Tanah Putih, the researcher used SPSS 22.0.

\section{Findings}

\subsection{The Data Presentation of the Students' Interest}

The data of the students' interest in listening at the eleventh-grade students of SMKN 3 Tanah Putih were collected by using questionnaire. After collecting the students' interest in listening to the eleventh-grade students of SMKN 3 Tanah Putih, the researcher then came to the data presented.

It is presented in the form of mean, mode, standard deviation, the highest and the lowest score which is completed with the variable description in the form of histogram. The computation of mean, median, mode, etc. the researcher used SPSS 20.00.

Table 1. The Frequency Distribution of the Students' Interest in Listening

\begin{tabular}{|c|c|c|c|c|}
\hline No & Score & Interpretation Level & Frequency & Percentage \\
\hline 1 & $81-100$ & Very Good & 1 & $4 \%$ \\
\hline 2 & $61-80$ & Good & 23 & $88 \%$ \\
\hline 3 & $41-60$ & Enough & 2 & $8 \%$ \\
\hline 4 & $21-40$ & Less & 0 & $0 \%$ \\
\hline 5 & $<21$ & Fail & 0 & $0 \%$ \\
\hline \multicolumn{3}{|c|}{ Total } & 26 & $100 \%$ \\
\hline
\end{tabular}

From table above, it can be concluded that a good score dominated the students' interest in listening. Then, the researcher examined the data presentation from the test by using SPSS version 22. Table 2. The Data Calculation of the Students' Interest in Listening

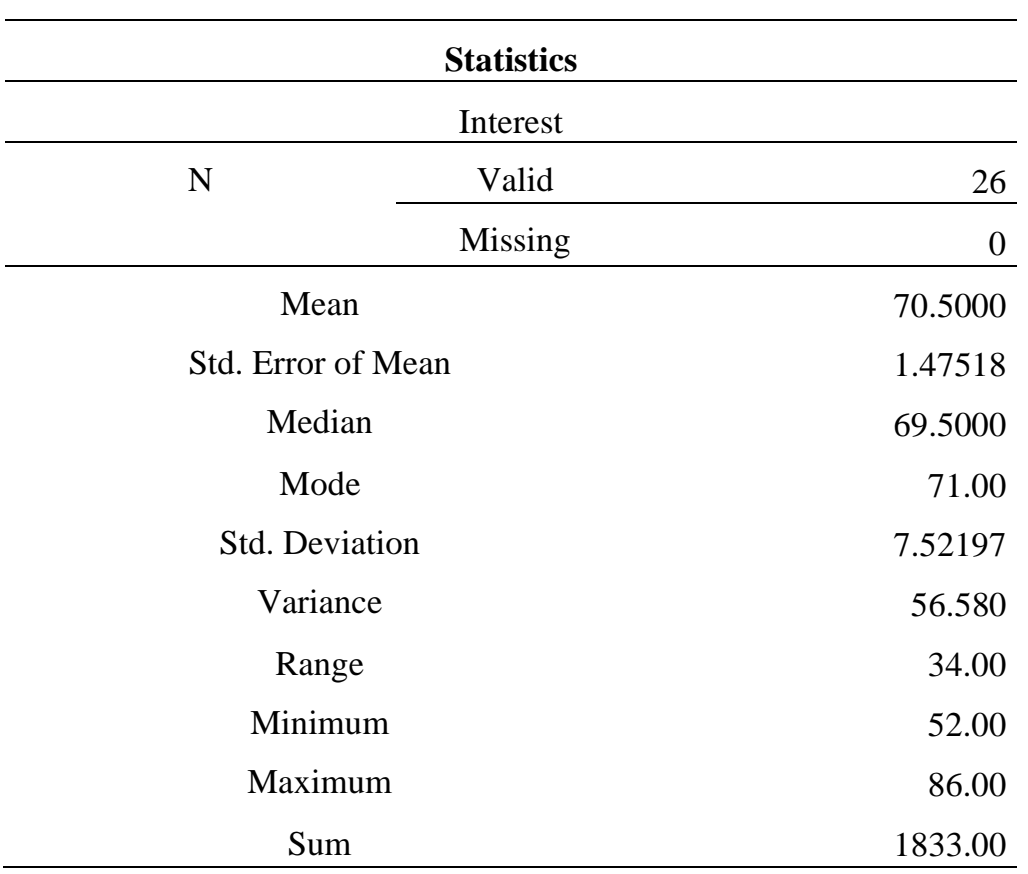

\subsection{The Data Presentation of the Students' Listening Comprehension}

Based on the calculation of the data about the students' interest in listening, the researcher got the result as follow:

The data of the students' listening comprehension at the eleventh-grade students of SMKN 3 Tanah Putih were collected by using listening 
comprehension test. Having done collecting the data about the students' listening comprehension at the eleventh grade students of SMKN 3 Tanah Putih, the researcher then comes to the data presentation. The students have good ability in listening comprehension. The mean score of students' interest in listening is 74 . The frequency distribution of the students' listening comprehension at the eleventhgrade students of SMKN 3 Tanah Putih were presented in the table as follow:

Table 3. The Frequency Distribution of the Students' Listening Comprehension at the Eleventh Grade Students of SMKN 3 Tanah Putih

\begin{tabular}{|c|c|c|c|c|}
\hline No & Score & Interpretation Level & Frequency & Percentage \\
\hline 1 & $81-100$ & Very Good & 4 & $15 \%$ \\
\hline 2 & $61-80$ & Good & 20 & $77 \%$ \\
\hline 3 & $41-60$ & Enough & 2 & $8 \%$ \\
\hline 4 & $21-40$ & Less & 0 & $0 \%$ \\
\hline \multirow[t]{2}{*}{5} & $<21$ & Fail & 0 & $0 \%$ \\
\hline & & Total & 26 & $100 \%$ \\
\hline
\end{tabular}

In data analysis of the students' listening comprehension at the eleventh-grade students of SMKN 3 Tanah Putih, the researcher examined the data presentation from the test by using SPSS version 22 .

Table 4. The Data Calculation of the Students' Listening Comprehension at the Eleventh Grade Students of SMKN 3 Tanah Putih

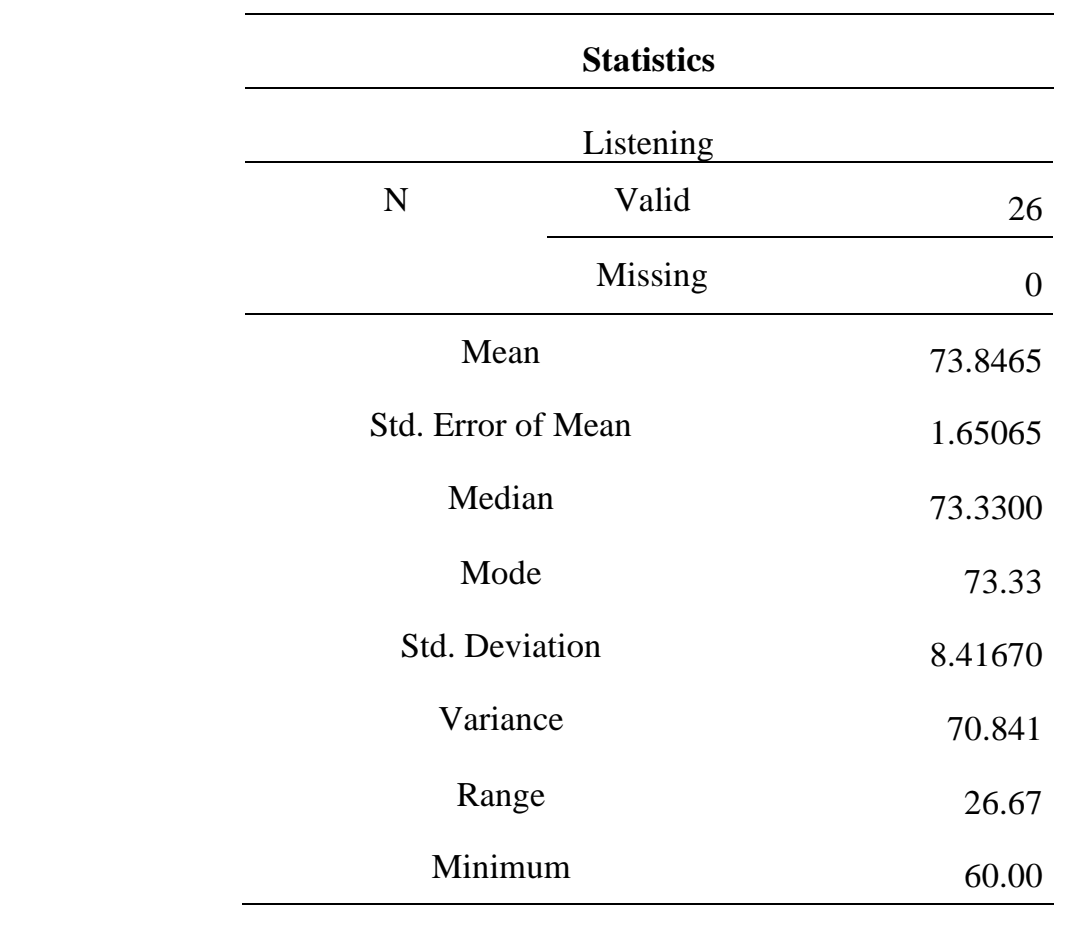

3.3 The Data Analysis of the Correlation of the Students' Interest in Listening and Their Listening Comprehension
Based on the calculation of the data about the students' listening comprehension at the eleventhgrade students of SMKN 3 Tanah Putih, the researcher got the result as follow:

The researcher's main goal was to find out whether there is a significant correlation between students' interest in listening and their listening comprehension on the eleventh-grade students of 
SMKN 3 Tanah Putih. To carry out the statistical analysis, the working hypothesis was changed into the Null Hypothesis to know about the correlation between students' interest in listening and their listening comprehension on the eleventh-grade students of SMKN 3 Tanah Putih.

After getting the scores of the students' interest in listening and their listening comprehension on the eleventh grade students of SMKN 3 Tanah Putih, the data were statistically computed to find out the correlation between the variables using SPSS version 22, where:

$$
\begin{aligned}
& \mathrm{X}=\text { The students' interest. } \\
& \mathrm{Y}=\text { The students' listening comprehension }
\end{aligned}
$$

In correlating those two variables, a statistical analysis that was used was Pearson Product Moment formula. The data, then, was calculated using SPSS Version 22.

Table 5. Analysis Result of Pearson Correlation Correlations

\begin{tabular}{|cc|r|r|}
\hline & & Interest & Listening \\
\hline Interest & Pearson Correlation & 1 & $.598^{* *}$ \\
& Sig. (2-tailed) & & .001 \\
& $\mathrm{~N}$ & 26 & 26 \\
\hline Listening & Pearson Correlation & $.598^{* *}$ & 1 \\
& Sig. (2-tailed) & .001 & \\
& $\mathrm{~N}$ & 26 & 26 \\
\hline
\end{tabular}

Based on the table above, the value of Sig. (2tailed) was 0.001 . According to the agreed rule, if the Sig. (2-tailed) value was less than 0.05 then the correlation is accepted to be significant, while on the contrary, if the Sig. (2-tailed) value is more than 0.05 so the correlation is refused to be significant. Since the Sig. (2-tailed) value was 0.001 (less than 0.05 ), it mean that the correlation between students' interest in listening and their listening comprehension on the eleventh grade students of SMKN 3 Tanah Putih was significant.

Based on the presentation and data analysis above, the researcher found the finding. The findings are:

a. The result of the students' interest in listening at the eleventh grade students of SMKN 3 Tanah Putih scores is 71 . It was a good interest.

b. The result of the students' listening comprehension at the eleventh grade students of SMKN 3 Tanah Putih is 74. It was a good score.

c. Sig. (2-tailed) result was 0.001 .

Criteria of the test:

Ho is accepted if probability (sig.) $>0.05$.

$\mathrm{Ha}$ is accepted if probability (sig.) $<0.05$

Because of Sig. (2-tailed) 0.001 was smaller than 0.05 , it can be concluded that null hypothesis (Ho) was rejected and alternative hypothesis (Ha) was accepted. In other word, the result of this research was there is significant correlatison between students' interest in listening and their listening comprehension on the eleventh grade students of SMKN 3 Tanah Putih.
The result of the study is in accordance with presented by Crow (2007: 248) that said interest may refer to the motivating force that impels students to attend to a person, a thing, or an activity. In other words, interest is as a power to force students to learn. Someone who has interest in listening will be forced to learn and practice it. But, someone who has no interest in listening will have no motivated to learn moreover have no motivated to practice it.

Interest is something which drives the person to participate in some activities. Interest can motivate students to enjoy the lesson. Besides that, high interest in listening comprehension makes the students possible concentrate on learning listening. The more the students' concentration on the lesson, the better the score they obtain, because concentration can increase the interesting. High-interesting students can arise a feeling and emotional connection to the lesson. The students who have a feeling and emotional connection to the material, they are easier to activate previous experience, and then the retention can be enhanced. Therefore their listening score is better.

Harackiewicz (2016) said the factors that can be used as a reflection of students who have an interest are pleasure, willingness, consciousness, and attention. Pleasure seems to be derived from simply watching the movements of people and objects. At the first, this activity is primarily biological, then perceptions occur and concepts begin to form. Listening is a psychological phenomenon, which 
takes place on a cognitive level inside people's heads, and a social phenomenon, which develops interactively between people and the environment surrounding them (Karagöz, 2017). In this case, the psychological components become more important. The child learns to avoid those activities as unsatisfying and to repeat those that have proved to be worthwhile. In other words, pleasure will emerge one's interest to objects or people that satisfy him.

Willingness means a motivational desire that is directed to the purpose of life controlled by thought. This motivational desire will produce a will, attention and concentration to a given object, and then the interest of the individual will appear. Then, a student can be said to be interested in something if student has consciousness. Student is conscious that he is doing the learning activity. Consciousness can exist in an individual when he has a will. When a student observes an object, he perceives only what he pays attention to or is interested in. by seeing the students' attention, it can be known whether he is interested in the object or not.

\section{Conclusion}

Interest does not exist itself. Interest cannot be possessed by anybody just that way, but it is something that can be developed and trained. A child's experience interferes whether he or she is going to be interested in something or not. The teachers have to know the factors in rising students' interest. The stimulus which is come from the environment related to someone's desires and needs is easier for him/her to build the interest. Someone's interest in one object or something not only caused by something come from inside of him or herself but also caused by social motive. Finally, the factor of feeling and emotion have effects to the object. Such as someone's experience in getting success in his/her life, it can raise enjoyment and spirit or have more interest in that activity.

\section{References}

Brown Douglas, H. (2004). Language Assessment: Principles and Classroom. Practice. New York: Pearson Education, Inc.

Byrne, D. (1976). Teaching Oral English: Longman handbooks for Language Teachers. Routledge.

Chasanah, U.Uswatun. (2017). The Correlation between Students' Interest in Listening English Songs and Vocabulary Mastery for the Second Grade Students of MTsN Tinawas in Academic Year 2016/2017. [Undergraduate Thesis. Surakarta: The State Islamic Institute of Surakarta]
Crawford, J. (2002). The role of materials in the language classroom: Finding the balance in Jack C. Richards and Willy A. Renandya (Eds.) Methodology in Language Teaching: An Anthology of Current Practice. https://viancep2012.files.wordpress.com/2011/ 12/methodology_in_language_teaching_2002_ scanned.pdf

Creswell, J. W. (2012). Educational Research: Planning, Conducting and Evaluating Quantitative and Qualitative Research 4th edition. Boston: Pearson Education Inc.

Crow, L.D., Crow, A. (2007). Educational Psychology, revised edition. New York: American Book Company.

Dornyei, Z. (2001). Teaching and Researching Motivation. London: Pearson Education Limited.

Douglas, B. H. (2001). Teaching by Principles: An Interactive Approach to Language Pedagogy Longman.

Firmani, S. H. (2009). The correlation between students interest and their achiement in learning english at the second year of SLPTN 1. [Undergraduate Thesis. Jakarta: Syarif Hidayatullah State Islamic University]dspace. https://repository.uinjkt.ac.id/dspace/bitstream/ 123456789/1507/1/SUFI\%20HUDAIBIAH\%2 OFIRMANI-FITK\%281\%29.pdf

Gay, L. R. (2012). Educational Research Competencies for Analysis and Applications. Tenth Edition. United States of America: Pearson Education.

Harackiewicz, J. M., Smith, J. L., \& Priniski, S. J. (2016). Interest matters: The importance of promoting interest in education. Policy insights from the behavioral and brain sciences, 3(2), 220-227.

Karagöz, B., Iscan, A., Baskin, S., \& Irsi, A. (2017). Investigation of Turkish Teacher Candidates Listening Skills. Universal Journal of Educational Research, 5(5), 750-756.

Renninger, K. A., \& Hidi, S. (2002). Student interest and achievement: Developmental issues raised by a case study. In Development of achievement motivation (pp. 173-195). Academic Press

Richards, J. C. (2008). Teaching listening and speaking. Cambridge: Cambridge university press. 
Richards, J. C., \& Schmidt, R. W. (2013). Longman dictionary of language teaching and applied linguistics. Routledge.

Rost, M. (2013). Teaching and researching: Listening. Routledge.

Sa'diyah, S. S. (2016). EFL learners-faced problems in listening comprehension. Indonesian EFL Journal, 2(1), 53-59.

Saville-Troike, M., \& Barto, K. (2016). Introducing second language acquisition. Cambridge University Press.

Saville-Troike, M. (2012). Introducing Second Language Acquisition - Second Edition. United States of America: Cambridge University Press.

Schiefele, Ulrich. (2009). Interest, Learning, and Motivation. Institutional Repository of Potsdam University.

Ulum, Ö. G. (2015). Listening: The Ignored Skill in EFL Context. Online Submission, 2(5), 72-76. 